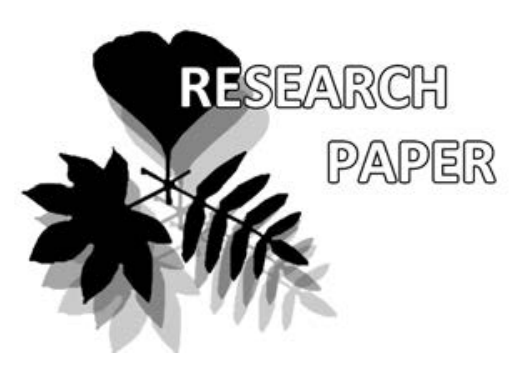

\title{
Low phenotypic plasticity of plants of monsoon tropical forest to light and their adaptation to scarce resources
}

\author{
Elena V. Novichonok ${ }^{1 *}$, Eugenia F. Markovskaya ${ }^{2}$, Artyom O. \\ Novichonok $^{2,3} \&$ Julia A. Kurbatova ${ }^{4}$
}

Elena V. Novichonok ${ }^{1 *}$

e-mail: enovichonok@inbox.ru

Eugenia F. Markovskaya ${ }^{2}$

e-mail: volev10@mail.ru

Artyom O. Novichonok 2,3

e-mail: artnovich@inbox.ru

Julia A. Kurbatova ${ }^{4}$

e-mail: kurbatova.j@gmail.com

${ }^{1}$ Forest Research Institute, Karelian Research Centre RAS, Petrozavodsk, Russia

${ }^{2}$ Petrozavodsk State University, Petrozavodsk, Russia

${ }^{3}$ Keldysh Institute of Applied Mathematics RAS, Moscow, Russia

${ }^{4}$ A.N. Severtsov Institute of Ecology and Evolution RAS, Moscow, Russia

* corresponding authors

Manuscript received: 09.04.2018

Review completed: 18.04.2018

Accepted for publication: 20.04.2018

Published online: 24.04.2018

\begin{abstract}
A B S T R A C T
Light is a limiting factor for plants growth and development in the tropical forest understory. At the same time, its characteristic feature is a highly heterogeneous distribution, to which the plants have to adapt. Adaptation is possible by means of phenotypic plasticity. We have assessed the phenotypic plasticity level of leaf parameters to the light factor in 17 species of undergrowth and understory layers. The majority of changes in leaf parameters in changing light conditions were determined by species differences ( $64.0 \%$ on average). The studied species were divided into six groups according to their plasticity level. For each group, different leaf characteristics played a key role in light adaptation. Consequently, each of the studied species had its own means of light adaptation, and the adaptation strategy in the undergrowth setting was aimed at adaptation to a narrow range of light conditions. This was reflected in the low level of plasticity (the mean of the relative distance plasticity index (RDPI) value was 0.12 ), which allowed species to occupy narrow ecological niches and ensured effective coexistence of plants in the context of limited resources.
\end{abstract}

K e y w o r d s : adaptation, gap, leaf traits, light, RDPI, understory

\section{P E 3 Ю M E}

Новичонок Е.В., Марковская Е.Ф., Новичонок А.О., Курбатова Ю.А. Низкая фенотипическая пластичность растений муссонного тропического меса к световому фактору и их аАаптация к ограниченному количеству ресурсов. Свет является ограничивающим факторов Аля роста и развития растений подроста и подлеска в тропических месах. При этом ААя него характерна сильная гетерогенность в распределении, к которой растения Аолжны аАаптироваться. ААаптация растений возможна за счет фенотипической пластичности. Нами была изучена степень фенотипической пластичности характеристик миста к световому фактору 17 видов подлеска и подроста. Бо́льшая часть изменений характеристик миста при изменении световых условий была обусловлена видовыми различиями (в среднем 64,0 \%). В соответствии с уровнем пластичности изученные виды были разАелены на 6 групп. А^я каждой группы при аАаптации к световому фактору важную роль играют разные характеристики Аиста. Показано, что каждый из изученных видов имеет собственный способ адаптации к уровню освещенности, а стратегия аАаптации в условиях подлеска направлена на приспособление к узкому диапазону световых условий. Это выражается в низком уровне пластичности (в среднем Аля всех изученных виАОв индекс пластичности относительных расстояний равнялся 0,12 ), что позволяет отАельным виАам занимать узкую экологическую нишу и обеспечивает успешное сосуществование растений в условиях ограниченного количества ресурсов.

КАючевые слова: адаптация, месные «окна», световой фактор, степень пластичности, поАлесок

\section{NTRODUCTION}

Tropical forests are a major component of the Earth's global ecosystems, since they influence climate, the hydrological and biogeochemical cycles, and harbor a significant portion of the planet's biological diversity (Huete et al. 2008). The last century experienced a rapid decrease in the area covered by tropical forests (Richards 1952, Lamb et al. 2005). In view of this, recently there has been an increased interest in the restoration and preservation and studies of tropical forest.
Light is one of the key abiotic factors maintaining the forest community structure. The solar irradiance is usually low and strongly modified in the understory layer of tropical monsoon forests (Richards 1952, Lüttge 2008). Light is considered to be the major limiting factor for the development and survival capacity of understory plants (Chazdon \& Fetcher 1984). The availability of light in the understory is often associated with regeneration processes and the capacity of forest species to survive in the long term (Whitmore 1996). At the same time, a high light heterogeneity is typical 
of tropical forests: the quality and amount of light reaching the understory can vary in a wide range due to the inhomogeneity of the forest canopy (Richards 1952, Kuznetsov 2003, Lüttge 2008). Moreover, in tropical forests, gaps are being constantly formed. Gaps can form naturally, as a result of windfall, or breaking of large branches and tree trunks (Kuznetsov \& Kuznetsova 2013). Selective felling are also widespread which leads to partial disruption of the canopy, which in its turn results in the emergence of gaps. The formation of a forest gap is accompanied by a change in the environmental conditions, especially the light level (Kuznetsov \& Kuznetsova 2013). This problem is aggravated by the fact that, in the course of evolution, understory plants have adapted to low light conditions (Zhang et al. 2000, Szarzynsk \& Anhuf 2001). The well-being of plants, their capacity for survival in the changing light conditions depends on their ability to adapt to different light levels.

An impotant characteristics of plants that enable them to survive under the changed light conditions is the adaptation of the photosynthetic apparatus (Bongers \& Popma 1988, Lichtenthaler \& Babani 2004, Sun et al. 2006). The production of alternative phenotypes by the same genotype in response to environmental differences can be defined as phenotypic plasticity (Sultan 2000, Delagrange et al. 2004, Markesteijn et al. 2007). However, at the present time plasticity is interpreted more widely. Theoretically, phenotypic plasticity should be studied on genetically homogeneous individuals. However, it is difficult to do in environmental studies and plasticity is often understood in a broader sense (Valladares et al. 2006).Plasticity enables plants to adapt to the heterogeneous environments and is beneficial for their growth and survival. However, the actual phenotypic plasticity is not always the highest possible which is associated with a number of factors that restrict plasticity, for instance, unfavourable abiotic factors, interspecies interactions, delayed plant reaction, the cost of maintenance of plasticity mechanisms (DeWitta et al. 1998). However, there is still no clear understanding of the causes and factors limiting the plasticity (Pigliucci 2005). In order to find a solution to this problem, it is necessary to conduct studies of the phenotypic plasticity of plants in the field, when a whole range of abiotic and biotic factors produce a combined effect on the plants.

High species diversity in tropical forest, the differences in their reactions to the environmental gradients create a complex structure of functional interaction. This system of natural cooperation will be changing with the changes in the plant leaf traits in response to the altered light conditions, which may ultimately lead to the change in the species composition and structure of the community. Still little is known about the influence that plasticity produces on the ecological interactions between plants in the community.

The assessment of the plasticity level and the capability of plants to adapt to the changing light conditions will throw light on its role in maintaining the tropical monsoon forest structure and will help predict the possible direction of the succession processes after the formation of gaps.

Thus the purpose of our study was explore the level of phenotypic plasticity of the photosynthetic apparatus to light in woody plants of tropical monsoon forest growing in the understory (either growing there constantly or being the new growth).

\section{MATERIAL AND METHODS}

\section{Study area}

This study was carried out in the Dong Nai Nature Reserve, situated in South Vietnam. The climate of South Vietnam is tropical monsoon (McKnight \& Hess 2000). The average yearly air temperature is $26-27^{\circ} \mathrm{C}$, the annual precipitation is $2450 \mathrm{~mm}$. There are two seasons in the year: the dry (November - April) and the wet season (May - October) (Blanc et al. 2000, Deshcherevskaya et al. 2013). In the territory of the national park, tropical monsoon rainforest prevails and it is characterized by a high biodiversity. The biodiversity index (the number of species to the number of individual plants ratio) equals 1:5.4 (Vandekerkhove et al. 1993).

\section{Plant collection}

The subjects of research were 17 plant species different in the growth form and position in the forest vertical structure that they occupy in a fully grown state (Table 1). The growth form was determined according to Pérez-Harguindeguy et al. (2013). At the moment of the study, all the plant species were growing in the understory under the same ecological conditions of growth, but at different stages of their ontogenesis: the plants in the fourth sublayer were occupying their typical habitat, whereas the other species were experiencing the early stages of their development and occupied the corresponding ecological niche.

For each species, 10 plants were selected that were growing in areas with a different scale of canopy disruption and, consequently, different light conditions. In total, 2 variants of the plant growth conditions were distinguished (5 plants in each), which were different in the degree of the canopy closure above the plants. Variant 1 - "understory" - plants growing in areas with intact canopy, characterized by a high degree of canopy cover and low light conditions; variant 2 - "gap" - plants growing in areas with damaged closure and high light conditions (Table 1). The degree of canopy closure in each case was estimated above each studied plant. It was determined as the proportion of sky hemisphere obscured by vegetation when viewed from a single point (Jennings et al. 1999). To assess the canopy closure, hemispherical photographs were taken using the Nicon D5200 with a fish-eye converter (Samyang $8 \mathrm{~mm}$ $\mathrm{f} / 3.5$ ). The analysis of images was made using the software WinSCANOPY (Paletto \& Tosi 2009). The canopy closure makes it possible to indirectly assess the PAR level reaching the canopy level (Jennings et al. 1999).

Samples of plant material were collected during the dry season (March - April 2012 and April 2013).

\section{Measurements of leaf traits}

The leaves were collected at 11-12 a.m. local time (UTC+7), which corresponds to the local midday (the maximum height of the sun over the horizon). Only fully unfolded leaves without epiphylls or defects were selected from the middle part of the canopy. 
Table 1. Characteristics of the studied species: growth form (GF), position in the vertical structure (VS), relative distance plasticity index (RDPI), environmentally standardized plasticity index (EPSI), mean canopy closure above plant in the understory (CCund) and gap (CCgap)

\begin{tabular}{|c|c|c|c|c|c|c|}
\hline Species (Family) & GF * & VS $* *$ & CCund $(\%)$ & CCgap $(\%)$ & RDPI & EPSI \\
\hline Lagerstroemia calyculata Kurz (Lythraceae) & ET & I & 85 & 45 & 0.16 & 0.07 \\
\hline Dipterocarpus alatus Roxb. ex G. Don. (Dipterocarpaceae) & ET & I & 80 & 5 & 0.16 & 0.08 \\
\hline Dalbergia sp. (Papilionaceae) & ET & II & 85 & 45 & 0.18 & 0.05 \\
\hline Hibiscus macrophyllus Roxb. ex Hornem. (Malvaceae) & DT & II - III & 70 & 30 & 0.19 & 0.18 \\
\hline Grewia paniculata Roxb. ex DC. (Tiliaceae) & DT & III & 75 & 20 & 0.14 & 0.05 \\
\hline Pterospermum sp. (Sterculiaceae) & ET & III & 90 & 50 & 0.17 & 0.05 \\
\hline Ochrocarpus siamensis T. And. (Clusiaceae) & ET & III & 85 & 55 & 0.07 & 0.04 \\
\hline Barringtonia cocbinchinensis (Miers) Merr. (Lecithidaceae) & ET & III & 75 & 55 & 0.07 & 0.14 \\
\hline Anaxagorea sp. (Annonaceae) & S & IV & 80 & 45 & 0.09 & 0.07 \\
\hline Cleistanthus sp. (Phyllanthaceae) & DwT & IV & 80 & 35 & 0.09 & 0.04 \\
\hline Phyllanthus sp. (Phyllanthaceae) & S & IV & 85 & 50 & 0.10 & 0.03 \\
\hline Ancistrocladus sp. (Ancistrocladaceae) & WV & II & 90 & 45 & 0.10 & 0.05 \\
\hline Baubinia sp. (Caesalpiniaceae) & WV & II & 85 & 25 & 0.11 & 0.05 \\
\hline Smilax sp. (Smilacaceae) & HV & III & 70 & 50 & 0.09 & 0.11 \\
\hline Korthalsia sp. (Arecaceae) & $\mathrm{HV}$ & III & 65 & 30 & 0.07 & 0.03 \\
\hline Calamus dioicus Lour. (Arecaceae) & $\mathrm{P}$ & II-III & 85 & 30 & 0.12 & 0.12 \\
\hline Licuala sp. (Arecaceae) & $\mathrm{P}$ & IV & 85 & 50 & 0.13 & 0.20 \\
\hline Average value & & & 80.6 & 37.4 & 0.12 & 0.08 \\
\hline
\end{tabular}

* GF: ET - excurrent tree, DT - deliquescent tree, DwT - dwarf tree, S - shrub, WV - woody vine, HV - herbaceous vine, P - palm

** Position in the vertical structure refer to plants in adulthood: I - first (upper) sublayer, II - second sublayer, III - third sublayer, IV fourth sublayer). Height of adult plant first (upper) sublaer is $30-50 \mathrm{~m}$, second sublayer $-15-30 \mathrm{~m}$, third sublayer $-5-15 \mathrm{~m}$, fourth sublayer $-2-4 \mathrm{~m}$

\section{Leaf morphology}

From each plant, 5 leaves were selected to determine the length $(\mathrm{LL} ; \mathrm{cm})$, width $(\mathrm{LW} ; \mathrm{cm})$, area $\left(\mathrm{LA} ; \mathrm{cm}^{2}\right)$ of the leaf blade, leaf slenderness (LS; $\mathrm{cm}^{\cdot \mathrm{cm}^{-1}}$ ) and specific leaf area $\left(\mathrm{SLA} ; \mathrm{m}^{2} \cdot \mathrm{g}^{-1}\right)$. The LL and LW were determined with the help of a millimetric ruler within the accuracy of $1 \mathrm{~mm}$. In Dalbergia sp. and Phyllanthus sp., separate folioles were measured with the help of a sliding caliper ruler with a division value of $0.1 \mathrm{~mm}$. The LS was determined as a ratio of LL to LW. For the measurement of the LA, the leaves were scanned. The LA was measured with the help of ImageJ software. To estimate the SLA, the leaf parts (without the midrib), with their area measured, were dried at $80^{\circ} \mathrm{C}$ until oven-dry mass and then weighed to determine the dry mass. The SLA was calculated as a leaf area to dry leaf mass ratio.

\section{Content of photosynthetic pigments}

From each plant, 2 leaves were selected to determine the photosynthetic pigments content and their proportion. The leaves were put into black plastic bags with ice and then taken to the laboratory. For the study the central part of the leaf plate was used, avoiding the midrib. The absolute photosynthetic pigment content was determined spectrophotometrically. The pigments were extracted with $96 \%$ ethanol. On the spectrophotometer (APEL, PD-303, Japan) the absorption was measured at wavelengths of 665 , 649 and $470 \mathrm{~nm}$. The mass-based (per unit dry mass of leaf; $\left.\mathrm{mg}^{\cdot \mathrm{g}^{-1}}\right)$ content of chlorophyll $a\left(\mathrm{Chl} a_{\text {mass }}\right)$, chlorophyll $b\left(\mathrm{Chl} b_{\text {mass }}\right)$ and carotenoids $\left(\mathrm{Car}_{\text {mass }}\right)$ in the extract was calculated by means of equations presented in the work of Wintermans \& De Mots (1965). The area-based $\left(\mathrm{mg} \cdot \mathrm{m}^{-2}\right)$ content of chlorophyll $a\left(\mathrm{Chl} a_{\text {area }}\right)$, chlorophyll b ( $\left.\mathrm{Chl} b_{\text {aree }}\right)$ and carotenoids (Car ${ }_{\text {area }}$ ) was calculated with regard to the SLA. Based on these data, the mass-based and area-based total chlorophyll content (Chl $a+b_{\text {mass }}, \mathrm{mg}^{\cdot} \mathrm{g}^{-1}$ and $\mathrm{Chl}$ $a+b_{\text {area }}, \mathrm{mg} \cdot \mathrm{m}^{-2}$ respectively), chlorophyll $a$ to chlorophyll $b$ ratio $(\mathrm{Chl} a / b)$, total chlorophyll content to carotenoids ratio (Chl/Car) was calculated. The light-harvesting complex (LHC) was calculated with an assumption that the total $\mathrm{Chl} b$ is included into the LHC and the Chl $a / b$ in the LHC equals 1.2 (Lichtenthaler 1987).

\section{Macronutrients content}

Five leaves from each plant were selected to determine the macronutrient content. The leaves without petioles and midribs were dried at $70^{\circ} \mathrm{C}$ until oven-dry mass. The mass-based nitrogen $\left(\mathrm{N}_{\text {mass }}, \mathrm{mg} \cdot \mathrm{g}^{-1}\right)$ concentrations were determined using the Kjeldahl digestion technique. The analysis of phosphorus $\left(\mathrm{P}_{\text {mass }}, \mathrm{mg} \cdot \mathrm{g}^{-1}\right)$ was made spectrophotometrically with ammonium-molybdate method. The mass-based potassium concentration $\left(\mathrm{K}_{\text {mass }}, \mathrm{mg} \cdot \mathrm{g}^{-1}\right)$ was determined by means of the atomic-emission method. The analysis of potassium was performed by a flame atomic spectrophotometer (AA-7000, Shimadzu, Japan). Based on these data, the area-based $\left(\mathrm{g} \cdot \mathrm{m}^{-2}\right)$ nitrogen $\left(\mathrm{N}_{\text {area }}\right)$, phosphorus $\left(\mathrm{P}_{\text {area }}\right)$ and potassium $\left(\mathrm{K}_{\text {area }}\right)$ concentrations were calculated.

\section{Estimation of phenotypic plasticity}

The phenotypic plasticity was measured using the relative distance plasticity index (RDPI) (Valladares et al. 2006). The relative distance (RD) was determined for all the speci- 
men pairs of the species growing under different conditions using the following formula: RD $i j \rightarrow i^{\prime} j^{\prime}=d i j \rightarrow i^{\prime} j^{\prime} /\left(x i^{\prime} j^{\prime}+x i j\right)$, where $d i j \rightarrow i^{\prime} j^{\prime}$ is distance among trait values for all pairs of individuals for which $i$ is different from $i^{\prime}$ (the two individuals were grown under different light environments); $x i j$ is the trait value of individual $j$ under light treatment $i, x i^{\prime} j^{\prime}$ is the trait value of individual $j^{\prime}$ under light treatment $i^{\prime}$.

The RPDI, which can vary from 0 (no plasticity) to 1 (maximum plasticity), was calculated according to the formula: RDPI $=\sum\left(d i j \rightarrow i^{\prime} j^{\prime} /\left(x i^{\prime} j^{\prime}+x i j\right)\right) / \mathrm{n}$, where $\mathrm{n}-$ total number of RD.

The RDPI, unlike other plasticity indexes, provides an opportunity to compare statistically the phenotypic plasticity of different leaf traits and of different species and rate these species according to their plasticity (Valladares et al. 2006).

In order to compare the influence of the light level on the plasticity of different species with due regard to the light variation range, we calculated the environmentally standardized plasticity index (EPSI) according to the following formula: EPSI $=(\mathrm{X}-\mathrm{x}) /|\mathrm{E}-\mathrm{e}|$, where $\mathrm{X}$ and $\mathrm{x}$ are the maximum and minimum mean phenotypic values of a given species across different environments, respectively, and $\mathrm{E}$ and $\mathrm{e}$ are the mean environmental values at which $\mathrm{X}$ and $\mathrm{x}$ were achieved (Valladares et al. 2006).

\section{Data analysis}

STATISTICA (data analysis software system), version 10 (StatSoft Inc.) was used for data analysis. The two-way ANOVA was conducted to determine the influence of the plant species and light level on the leaf traits. The cluster analysis was used for the grouping of the species according to the RDPI. The data were first standardized. Ward's method was used for clustering species, because it gives a clearer and better-defined structure of the clusters (Fielding 2007). The squared Euclidean distance was used as a distance coefficient. The significance of differences of the arithmetic mean values was estimated using Student's t-test (two independent groups) and the Newman-Keuls test (for more than two groups).

\section{RESULTS}

Having analyzed the dependence of the leaf traits from the light conditions in which the plants had been growing, we came to the following conclusions: the values of all the studied leaf traits largely depended on the plant species $(p<0.001)$, and the difference in leaf traits among species explained most of the leaf trait variation (mean is $64.0 \%$ ). The light level produced an impact on 16 (out of 22) leaf traits and accounted for just a little portion of the leaf trait variation (mean $3.5 \%$ ). Species and light effect was observed for 20 leaf traits and, on average, accounted for $16.2 \%$ of the leaf trait variation (Table 2 ).

For all the studied species, a low level of plasticity was reported. The RDPI varied from 0.07 to 0.19 (mean is 0.12 ) (Table 1). The EPSI values were also low (mean is 0.08). However, for two species, Hibiscus sp. and Licuala sp., higher values of EPSI were typical, as compared to the other studied species (Table 1).
No significant difference was revealed in the plasticity level between the 3 groups of leaf traits (morphological parameters, the content of photosynthetic pigments, the content of macronutrients) (Table 3). In addition, the RDPI of most of the studied traits was similar. Only such parameters as LL, LW, LS, the ratios of photosynthetic pigments content (Chl $a / b, \mathrm{Chl} / \mathrm{Car})$ and LHC had a lower plasticity level in comparison with the other studied leaf traits (Table 3).

The results of the cluster analysis showed that according to RDPI all the studied plant species can be divided into 6 groups (Fig. 1). This being said, the studied species are grouped regardless of their growth form and position of species in the forest vertical structure. The clusters were significantly different in the RDPI of the following leaf traits: the content of photosynthetic pigments per mass $(\mathrm{Chl} a, \mathrm{Chl} b, \mathrm{Chl}(a+b))$ and per area (Chl $b, \mathrm{Chl}(a+b)$, Car), SLA, the concentrations of $\mathrm{N}$ and $\mathrm{P}$ per mass and per area (Fig. 1, 2). In addition, for plant species belonging to clusters II and IV, higher RDPI was observed for the content of photosynthetic pigments as compared to the content of macronutrients. At the same time, in species included into clusters III and VI, at the changes in the light level the content of macronutrients changes more significantly than the content of photosynthetic pigments. In species from cluster $\mathrm{V}$ the highest plasticity was observed associated with the SLA; in species from cluster I - the one associated with the content of photosynthetic pigments and mineral elements calculated in terms of the leaf area (Fig. 1,2).

To determine how the plants share the light niches, what groups they form when they are all in the understory under the conditions of intact natural forest, a cluster analysis has been conducted. According to the leaf trait under the conditions of intact canopy ("understory" variant), 4 groups of species have been distinguished (Fig. 3). In so doing, the species were grouped regardless of their growth form or the position they occupied in the forest vertical structure. The leaf length, SLA, the content of photosynthetic pigments (for both per unit leaf area and per unit dry leaf mass), the Chl/Car ratio and $\mathrm{N}_{\text {area }}$ are different in plant species belonging to different clusters (Fig. 4). For species from cluster I it is typical to have the lowest content of photosynthetic pigments (Chl $a$, Chl $b, \mathrm{Chl}(a+b)$ and Car) per

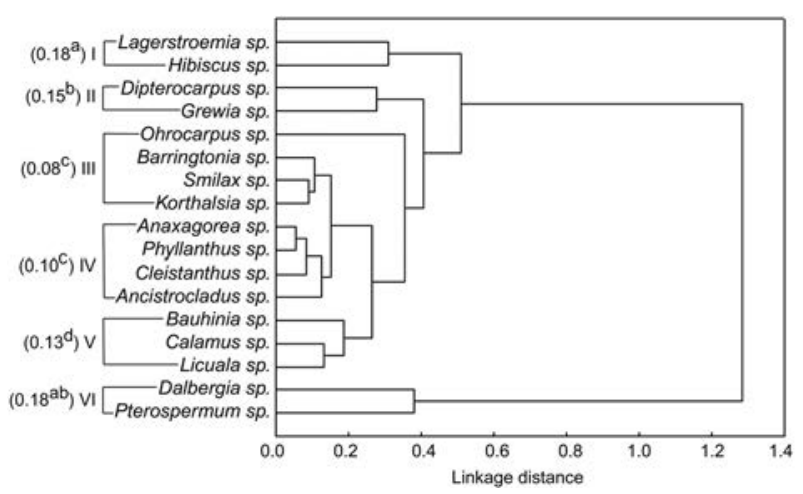

Figure 1 Results of cluster analysis for RDPI. The roman numerals indicate the numbers of clusters. In brackets, the mean RDPI for each cluster. Different superscript letters indicate significant differences among clusters at $\mathrm{p}<0.05$ 
Table 2. Two-way ANOVA with the effect of species and light level on leaf traits

\begin{tabular}{|c|c|c|c|c|c|c|c|c|c|c|}
\hline \multirow{2}{*}{ Leaf trait } & \multirow[b]{2}{*}{$\mathbf{n}$} & \multicolumn{2}{|c|}{ Species } & \multirow[b]{2}{*}{$\eta^{2}$} & \multicolumn{3}{|c|}{ Light } & \multicolumn{3}{|c|}{ Species $_{*}$ Light } \\
\hline & & $\mathbf{F}$ & $\mathrm{p}^{\#}$ & & F & $\mathrm{p}^{\#}$ & $\eta^{2}$ & $\mathbf{F}$ & $\mathrm{p}^{\#}$ & $\eta^{2}$ \\
\hline LL & 17 & 78.8 & $* * *$ & 84.9 & 7.6 & $* *$ & 0.5 & 3.0 & $* * *$ & 3.2 \\
\hline LW & 17 & 80.8 & $* * *$ & 83.1 & 10.6 & $* *$ & 0.7 & 5.1 & $* * *$ & 5.2 \\
\hline LS & 17 & 192.0 & $* * *$ & 92.6 & 6.1 & $*$ & 0.2 & 4.3 & $* * *$ & 2.1 \\
\hline LA & 17 & 42.6 & $* * *$ & 75.7 & 0.3 & ns & 0.03 & 11.6 & $* * *$ & 20.5 \\
\hline SLA & 16 & 21.3 & $* * *$ & 67.5 & 35.8 & $* * *$ & 7.6 & 5.7 & $* * *$ & 18.2 \\
\hline $\mathrm{Chl} a_{\text {mass }}$ & 16 & 25.6 & $* * *$ & 50.7 & 53.0 & $* * *$ & 7.0 & 10.6 & $* * *$ & 21.1 \\
\hline $\mathrm{Chl} b_{\text {mass }}$ & 16 & 18.8 & $* * *$ & 39.6 & 92.9 & $* * *$ & 13.1 & 11.8 & $* * *$ & 24.9 \\
\hline $\operatorname{Chl}(a+b)_{\text {mass }}$ & 16 & 25.2 & $* * *$ & 47.2 & 76.0 & $* * *$ & 9.5 & 12.5 & $* * *$ & 23.3 \\
\hline $\mathrm{Car}_{\text {mass }}$ & 16 & 27.5 & $* * *$ & 55.1 & 16.7 & $* * *$ & 2.2 & 10.6 & $* * *$ & 21.3 \\
\hline $\mathrm{Chl} a_{\text {area }}$ & 16 & 38.1 & $* * *$ & 62.0 & 12.4 & $* * *$ & 1.3 & 11.9 & $* * *$ & 19.3 \\
\hline $\mathrm{Chl} b_{\text {area }}$ & 16 & 33.1 & $* * *$ & 58.6 & 0.1 & ns & 0.01 & 12.7 & $* * *$ & 22.5 \\
\hline $\mathrm{Chl}(a+b)_{\text {area }}$ & 16 & 41.3 & $* * *$ & 62.3 & 6.8 & $*$ & 0.7 & 13.9 & $* * *$ & 20.9 \\
\hline $\mathrm{Car}_{\text {area }}$ & 16 & 34.2 & $* * *$ & 59.2 & 27.7 & $* * *$ & 3.2 & 11.0 & $* * *$ & 19.1 \\
\hline $\mathrm{Chl} a / b$ & 16 & 3.9 & $* * *$ & 23.8 & 2.5 & ns & 1.0 & 1.5 & $\mathrm{~ns}$ & 9.4 \\
\hline $\mathrm{Chl} / \mathrm{Car}$ & 16 & 8.7 & $* * *$ & 30.0 & 52.1 & $* * *$ & 11.9 & 6.3 & $* * *$ & 21.6 \\
\hline LHC & 16 & 6.8 & $* * *$ & 34.5 & 11.4 & $* * *$ & 3.8 & 1.6 & ns & 8.0 \\
\hline $\mathrm{N}_{\text {mass }}$ & 17 & 139.4 & $* * *$ & 85.5 & 0.7 & ns & 0.03 & 21.4 & $* * *$ & 13.1 \\
\hline $\mathrm{P}_{\text {mass }}$ & 17 & 58.0 & $* * *$ & 66.5 & 0.6 & ns & 0.04 & 27.1 & $* * *$ & 31.0 \\
\hline $\mathrm{K}_{\text {mass }}$ & 17 & 116.5 & $* * *$ & 92.0 & 1.0 & ns & 0.05 & 8.0 & $* * *$ & 6.3 \\
\hline $\mathrm{N}_{\text {area }}$ & 16 & 250.1 & $* * *$ & 86.0 & 67.8 & $* * *$ & 1.6 & 34.2 & $* * *$ & 11.8 \\
\hline $\mathrm{P}_{\text {area }}$ & 16 & 112.1 & $* * *$ & 68.4 & 153.3 & $* * *$ & 6.2 & 39.3 & $* * *$ & 24.0 \\
\hline $\mathrm{K}_{\text {area }}$ & 16 & 144.7 & $* * *$ & 82.9 & 178.8 & $* * *$ & 6.8 & 15.8 & $* * *$ & 9.1 \\
\hline
\end{tabular}

${ }^{\#} p$ - level of significance: $* p<0.05 ; * * p<0.01$; *** $p<0.001$, ns - not significant $(p>0.05)$.

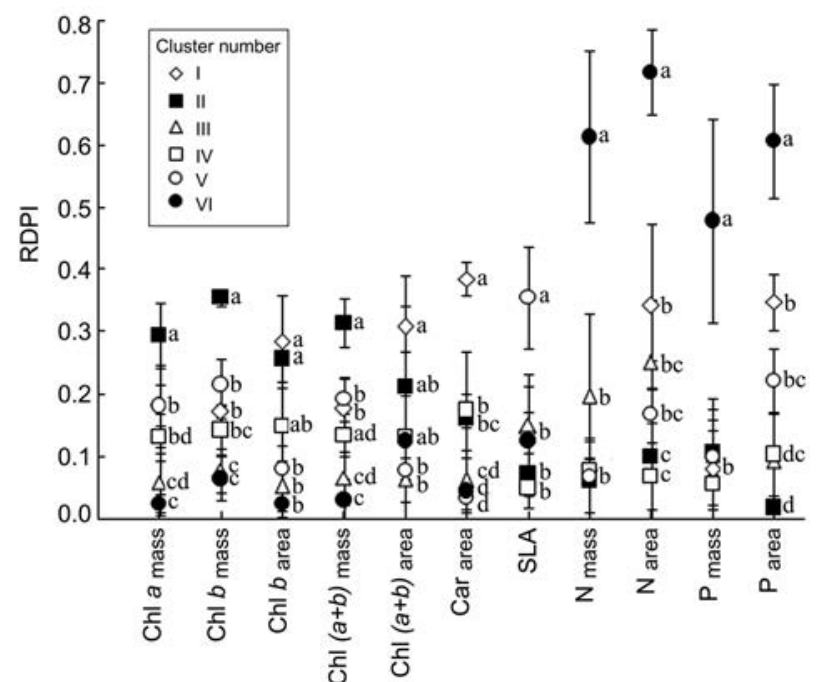

Figure 2 Average values of the leaf trait plasticity in which the clusters have significant differences $(\mathrm{p}<0.05)$. Standard deviations are shown. The cluster numbers $(\mathrm{I}-\mathrm{VI})$ correspond to the ones given in Fig. 1. Different letters indicate the clusters with significant differences at $\mathrm{p}<0.05$. Abbreviations: Chl $a_{\text {mass }}$ and Chl $b$ - mass-based content of chlorophyll $a$ and chlorophyll $b$; $\mathrm{Chl}^{\text {mars }}$ area and $\mathrm{Car}_{\text {area }}$ - area-based content of chlorophyll $b$ and carotenoids; Chl $a+b$ and Chl $a+b$ - mass-based and areabased total chlorophyll content; SLA - specific leaf area; Nmass (Narea) and Pmass (Parea) - mass-based (area-based) nitrogen and phosphorus content unit leaf area and the highest values of SLA and Chl/Car. Species in cluster III are characterized by the lowest content of photosynthetic pigments ( $\mathrm{Chl} a, \mathrm{Chl} b, \mathrm{Chl}(a+b))$ per unit dry leaf mass and the lowest values of SLA. For Dipterocarpus sp., Baubinia sp. and Korthalsia sp. (cluster II) it is typical to have the highest content of $\mathrm{Chl} a, \mathrm{Chl}(a+b)$ and Car per unit dry leaf mass, compared to the other studied species (Fig. 4).

\section{DISCUSSIO N}

Light is an important ecological factor which influences the growth, survival and competitive performance of plants in a community (Valladares 2003). It is conventionally believed that light exerts great influence on the structural and functional traits of plants (Givnish 1988, Niinemets \& Valladares 2004, Sultan \& Bazzaz 1993, Valladares \& Niinemets 2008). However, in our study we have not observed any strong influence of light on the studied leaf traits: light only accounted for $3.5 \%$ of the leaf trait variations. Most of the variations in the leaf traits $(64.0 \%$ on average $)$ in our study were associated to species differences (Table 2). The weak changes in the leaf traits at strong variations of the light level and the high interspecies variation of these properties were also noted by other researchers who studied the plasticity of plant leaves growing in the zone of dry (Markesteijn et al. 2007) and moist (Rozendaal et al. 2006) tropical forests. Species and light effect was reported for most of the studied leaf traits, which is indicative of dif- 
Table 3. Relative distance plasticity index (RDPI) for leaf traits (mean \pm standard error of the mean)*

\begin{tabular}{|c|c|}
\hline Leaf trait & RDPI \\
\hline \multicolumn{2}{|c|}{ Leaf morphology } \\
\hline LL & $0.08 \pm 0.01^{\text {a }}$ \\
\hline LW & $0.06 \pm 0.01^{\text {a }}$ \\
\hline LS & $0.06 \pm 0.01^{\text {a }}$ \\
\hline LA & $0.15 \pm 0.03^{\mathrm{b}}$ \\
\hline SLA & $0.15 \pm 0.03^{\mathrm{b}}$ \\
\hline Average value & $0.10 \pm 0.02$ \\
\hline \multicolumn{2}{|c|}{ Content of photosynthetic pigments } \\
\hline $\mathrm{Chl} a_{\text {mass }}$ & $0.14 \pm 0.02^{\text {a }}$ \\
\hline $\mathrm{Chl} b_{\text {mass }}$ & $0.16 \pm 0.02^{\text {a }}$ \\
\hline $\operatorname{Chl}(a+b)_{\text {mass }}$ & $0.14 \pm 0.02^{\text {a }}$ \\
\hline $\mathrm{Car}_{\text {mass }}$ & $0.10 \pm 0.02 \mathrm{ac}$ \\
\hline Chl $a_{\text {area }}$ & $0.15 \pm 0.03^{\text {a }}$ \\
\hline $\mathrm{Chl} b b_{\text {area }}$ & $0.13 \pm 0.03^{\text {a }}$ \\
\hline $\mathrm{Chl}(a+b)_{\text {area }}$ & $0.14 \pm 0.02^{\text {a }}$ \\
\hline $\mathrm{Car}_{\text {area }}$ & $0.13 \pm 0.03$ a \\
\hline $\mathrm{Chl} a / b$ & $0.04 \pm 0.01 \mathrm{~b}$ \\
\hline $\mathrm{Chl} / \mathrm{Car}$ & $0.06 \pm 0.01 \mathrm{bc}$ \\
\hline LHC & $0.02 \pm 0.003^{b}$ \\
\hline Average value & $0.11 \pm 0.01$ \\
\hline \multicolumn{2}{|c|}{ Macronutrients content } \\
\hline $\mathrm{N}$ (mass) & $0.17 \pm 0.05^{\text {a }}$ \\
\hline $\mathrm{N}_{\text {mass }}$ & $0.13 \pm 0.04^{\text {a }}$ \\
\hline$P_{\text {mass }}^{\text {mass }}$ & $0.09 \pm 0.01^{\mathrm{b}}$ \\
\hline $\mathrm{K}_{\text {mass }}$ & $0.24 \pm 0.05^{\text {a }}$ \\
\hline $\mathrm{N}_{\text {area }}$ & $0.20 \pm 0.05^{\text {a }}$ \\
\hline $\mathrm{P}_{\text {area }}$ & $0.18 \pm 0.02^{\text {a }}$ \\
\hline Average value & $0.17 \pm 0.02$ \\
\hline
\end{tabular}

*Different superscript letters indicate significant difference at $p<0.05$ (separately for leaf morphology, content of photosynthetic pigments and macronutrients content)

ferent responses to the changes in the light levels. Results indicate that each of the studied species has its own way of adaptation to lighting environments.

The cluster analysis for leaf traits of plants growing under the conditions of intact canopy ("understory" variant) gave us an opportunity to divide all the studied plant species into 4 groups (Fig. 3). The species were grouped regardless of their growth form or position they occupied in the community vertical structure. A further analysis showed that the leaf length, SLA, the content of photosynthetic pigments (for both per unit leaf area and per unit dry mass), the Chl/ Car ratio and $\mathrm{N}_{\text {area }}$ are different in plant species belonging to different clusters (Fig. 4). The differences in these leaf traits make it possible for species growing side by side to specialize in separate light niches. For Dipterocarpus sp., Baubinia sp. and Korthalsia sp. (cluster II) it is typical to have the highest content of $\mathrm{Chl} a$, Chl $(a+b)$ and Car per unit dry mass, compared to the other studied species. This is indicative of the fact that in the setting of understory, these species (Dipterocarpus sp., Baubinia sp. - at early stages of development, Korthalsia sp. - in the course of its entire ontogenesis) are capable of successful growth and development in a more shaded light niche, as compared to the other studied spe- cies. The species in clusters I and III are characterized by such leaf traits that indicate that they are adapted to a light niche with more accessible light, as compared to species in clusters II and IV. For species from cluster I it is typical to have the lowest content of photosynthetic pigments ( $\mathrm{Chl} a$, $\mathrm{Chl} b$, Chl $(a+b)$ and Car) per unit leaf area, and the highest values of SLA and Chl/Car. Species in cluster III are characterized by a low content of photosynthetic pigments $(\mathrm{Chl} a, \mathrm{Chl} b, \mathrm{Chl}(a+b))$ per unit leaf mass and the lowest values of SLA (Fig. 3, 4). The low photosynthetic pigments content in species from clusters I and III, as compared to clusters II and IV, does not let them occupy very shaded light niches. The reported lowest values of photosynthetic pigments content in species of cluster III per unit dry leaf mass and the equating of these values to species of clusters II and IV per unit leaf area is associated with the low SLA values. The low SLA values in combination with a low content of photosynthetic pigments per dry leaf mass lead to an increase values of the photosynthetic pigments content per unit leaf area. Despite the similarities between species from clusters I and III (a need for higher light level), there are certain differences between them. For instance, for species in cluster I, the highest SLA values are typical, which enhances the absorption efficiency of light even at a low content of photosynthetic pigments. In contrast to them, species in cluster III have the lowest values of SLA, which in combination with a low content of photosynthetic pigments leads to a situation when for successful growth and development they need high light level, and they are ill-adapted (worse than the other species) to the understory conditions. Thus, the analysis of leaf traits that the clusters have significant differences in, enables us to arrange the studied species according to their demand for the light niche. In the order from least to most light-demanding species, they can be arranged in the following way: species of cluster II $<$ IV $<$ I $<$ III.

The leaf traits with the highest plasticity level are key in the adaptation of plants to the light conditions (Bongers \& Popma 1988). No significant difference was revealed in the plasticity level between the 3 groups of leaf traits (morphological parameters, the content of photosynthetic pigments,

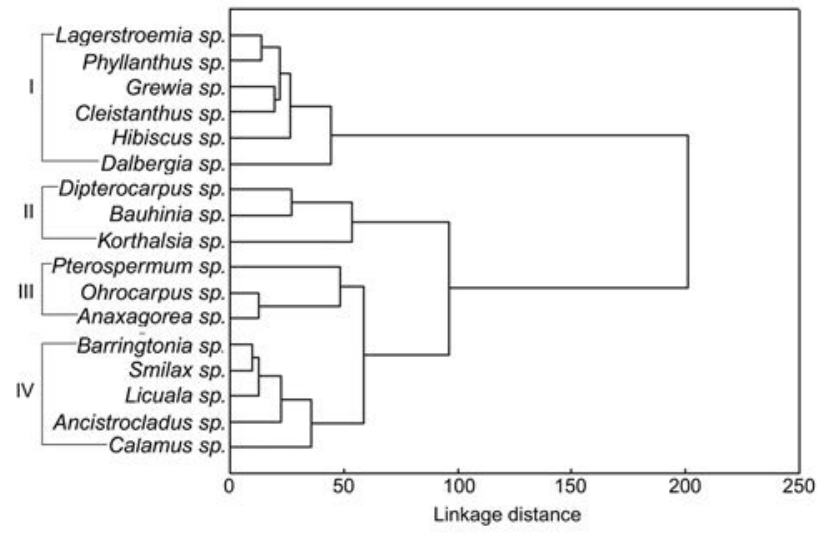

Figure 3 Species groups according to the leaf traits under the conditions of intact canopy (the cluster analysis results). The roman numerals indicate the numbers of clusters 
the content of macronutrients) (Table 3). Researchers working in tropical forests discovered that a higher level of plasticity is typical for such parameters as SLA, mineral elements (N and P) content in the leaf, the $\mathrm{Chl}$ to $\mathrm{N}$ ratio. These leaf traits are important for the adaptation of plants to the light conditions, since they are associated with the photosynthetic rate and carbon balance in the plant (Markesteijn et al. 2007, Rozendaal et al. 2006). We have noted that LL, LW, $\mathrm{LS}$ and the photosynthetic pigments ratios $(\mathrm{Chl} a / b$, $\mathrm{Chl} / \mathrm{Car}, \mathrm{LHC}$ ) had a lower level of plasticity, as compared to the other studied leaf traits the plasticity level of which was almost the same. Perhaps, the absence of clearly distinguishable leaf traits with a higher plasticity level is connected with the fact that different species adapt to light level by means of different mechanisms. To confirm this hypothesis we conducted a cluster analysis. The results showed that according to the level of plasticity to the light factor all the studied species can be divided into 6 groups, and for each group in the adaptation to the light level different leaf traits play a very important role (Fig. 1, 2). For instance, for species included into clusters II and $\mathrm{IV}$, the most important role in the adaptation to the light conditions is played by the content of photosynthetic pigments. At the same time, in species included into clusters III and VI, at the change of the light level the content of mineral elements changes more significantly, as compared to the content of photosynthetic pigments. In species from cluster $\mathrm{V}$ the highest plasticity was observed associated with the SLA; in species from cluster I - the one associated with the content of photosynthetic pigments and mineral elements calculated in terms of the leaf area.

Consequently, each of the studied species has its own way of adaptation to lighting environments. Moreover, these adaptation ways are different, which results in different leaf trait values. Perhaps, it is these differences in the leaf traits that provide the growth of a large number of species under the same conditions of understory in the tropical monsoon forest. This suggests that in the tropical monsoon forest, plants growing in the understory (at an early stage of their development or throughout their whole ontogenesis) strive to occupy their own narrow ecological niche, which enables them to reduce competition in the context of very scarce resources.

It is believed that phenotypic plasticity is one of the key mechanisms enabling plants to adapt to the light conditions (Bradshaw 1965, Sultan 2000, Delagrange et al. 2004). However, the level of plasticity to the light factor in all the studied species was low (Table 1). There is an opinion that the plasticity level depends on what particular changes in light can happen in the course of plant ontogenesis. Plant species which at the beginning of their life cycle find themselves in shaded conditions (in the understory layer), and then in the course of their growth are exposed to higher light must have a higher degree of plasticity, as compared to species who have always been growing in the understory (Popma et al. 1992). Yet, the conducted analysis has not revealed any difference in the plasticity level (RDPI and

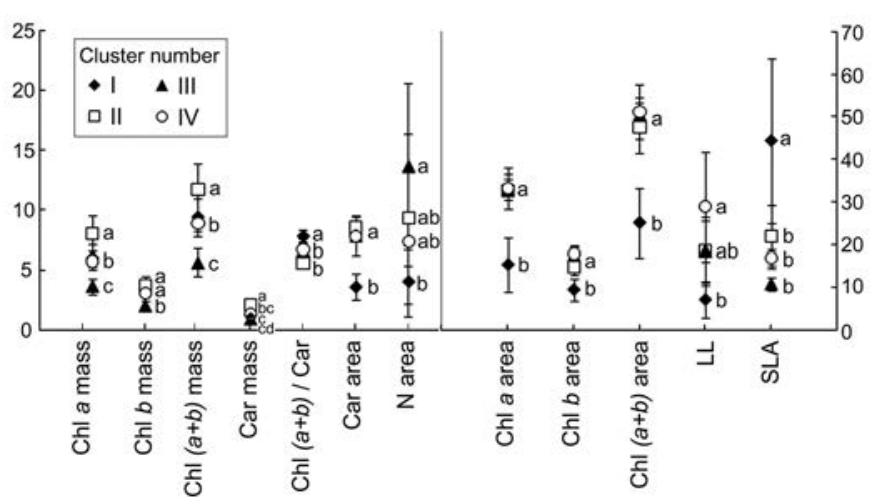

Figure 4 Values of leaf trait under the conditions of intact canopy ("understory" variant) in which the clusters have significant differences $(\mathrm{p}<0.05)$. Standard deviations are shown. The cluster numbers (I-IV) correspond to the ones given in Fig. 3. Different letters indicate the clusters with significant differences at $\mathrm{p}<0.05$. Abbreviations: $\mathrm{Chl} a_{\text {mass }}\left(\mathrm{Chl} a_{\text {are }}\right)$, $\mathrm{Chl} b_{\text {mass }}\left(\mathrm{Chl} b_{\text {area }}\right), \mathrm{Car} \mathrm{rass}_{\mathrm{m}}\left(\mathrm{Car}_{\text {area }}\right)$ and $\mathrm{Chl} a+b_{\text {mass }}\left(\mathrm{Chl} a+b_{\text {area }}\right)-$ massbased (area-based) content of chlorophyll $a$, chlorophyll $b$, carotenoids and total chlorophyll content; SLA - specific leaf area; $\mathrm{N}_{\text {area }}$ - area-based nitrogen content; LL - length of the leaf blade

EPSI) between species occupying a different position in the community vertical structure. This can be connected with the fact that different plant species, regardless of the height they are going to reach in a fully grown state, while growing in the understory layer will not profitably from having a higher degree of plasticity. This may be caused by the fact that a high plasticity level requires greater metabolic costs and can be in inverse proportion to their competitive ability and survivability under the conditions of low light (SánchezGómez et al. 2006). As was shown, the low plasticity level is associated with a conservative, more stable reaction of the plant to environmental changes (Grubb 1998, Valladares et al. 2000). A decrease in plasticity to the light may be part of the overall conservative strategy of resource use in plant species and their high resistance to shading (Grubb 1998, Lei \& Lechowicz 1998, Grime \& Mackey 2002).

Previously it was shown that at the decrease in the species composition of communities, which leads to a decrease in the taxonomical and adaptive diversity, one can observe phenomena of a compensatory nature in the communities, and among these phenomena, for instance - the expansion of ecological niches and an increase in the intraspecific diversity (Chernov 2005). The low level of plasticity observed in the studied species indicates that plant species under the conditions of tropical monsoon forest understory perform a narrow range of synecological functions. As a result, they occupy narrow ecological niches (which was shown above). In light of this, it can be assumed that plants growing in forest communities characterized by a low species diversity (as compared to plants of multispecies communities) will possess a higher level of phenotypic plasticity, which enables them to occupy a wider range of ecological niches and to make the most use of the available resources.

As can be seen from the above, the adaptation strategy of species under the conditions of tropical monsoon forest understory is aimed at adapting to a particular narrow range of ecological factors. This is reflected in the low plasticity 
level, enables them to occupy a narrow ecological niche and ensures successful coexistence of plants in the context of scarce resources.

\section{ACKNOWLEDGEMENTS}

This research was carried out with the support of the Joint Russian-Vietnam Tropical Research and Technological Centre. We thank the administration and staff of the Tropical Centre for the possibility of working in Vietnam, as well as the administration of the Dong Nai Nature Reserve, where all the experimental studies were executed. The analysis of macronutrients content was carried out using the equipment of the Core Facility of the Karelian Research Centre of the Russian Academy of Sciences. The study was carried out under state order to the Karelian Research Centre of the Russian Academy of Sciences (project № 0220-2017-0002). The work of J. Kurbatova was partially supported by RFBR and Russian Geographical Society according to the research project № 17-05-41127 and was funded by the Presidium of the Russian academy of sciences, Program No 41 "Biodiversity of natural systems and biological resources of Russia". We thank Svetlana Filon for providing language support.

\section{LITERATURE CITED}

Blanc, L., G. Maury-Lechon \& J.-P. Pascal 2000. Structure, floristic composition and natural regeneration in the forests of Cat Tien National Park, Vietnam: an analysis of the successional trends. Journal of Biogeography 27 (1):141157.

Bongers, F. \& J. Popma 1988. Is exposure-related variation in leaf characteristics of tropical wet forest species adaptive? In: Plant form and vegetation structure: adaptation, plasticity, and relation to herbivory (M.J.A. Werger, P.J.M. van der Aart, H.J. During \& J.T.A. Verhoeven, eds), pp. 191-200, SPB Academic Publishing, Hague, The Netherlands.

Bradshaw, A.D. 1965. Evolutionary significance of phenotypic plasticity in plants. Advances in Genetics 13:115-155.

Chazdon, R.L. \& N. Fetcher 1984. Photosynthetic light environments in a lowland tropical rain forest in Costa Rica. Journal of Ecology 72(2):553-564.

Chernov, Yu.I. 2005. Species diversity and compensatory phenomena in communities and biological systems. Zoologicheskii Zhyrnal 84(10):1221-1238 (in Russian with English summary). [Чернов Ю.И. 2005. Виловое разнообразие и компенсационные явления в сообществах и биотических системах // Зоологический журнал. Т.84, №10. C.1221-1238].

Delagrange, S., C. Messier, M.J. Lechowicz \& P. Dizengremel 2004. Physiological, morphological and allocational plasticity in understory deciduous trees: importance of plant size and light availability. Tree Physiology 24(7):775-784.

Deshcherevskaya, O.A., V.K. Avilov, B.D. Dinh, C.H. Tran \& J.A. Kurbatova 2013. Modern climate of Cat Tien national park (Southern Vietnam): climatological data for ecological studies. Irvestiya, Atmospheric and Oceanic Physics 49(8):819-838.

DeWitta, T.J., A. Siha \& D.S. Wilson 1998. Costs and limits of phenotypic plasticity. Trends in Ecology and Evolution 13(2):77-81.

Fielding, H.A. 2007. Cluster and classification techniques for the biosciences. Cambridge University Press, Cambridge, pp. 46-68.
Givnish, T.J. 1988. Adaptation to sun and shade: a wholeplant perspective. Australian Journal of Plant Physiology 15(2):63-92.

Grime, J.P. \& J.M.L. Mackey 2002. The role of plasticity in resource capture by plants. Evolutionary Ecology 16(3):299_ 307.

Grubb, P.J. 1998. A reassessment of the strategies of plants which cope with shortages of resources. Perspectives in Plant Ecology, Evolution and Systematics 1(1):3-31.

Huete, A.R., N. Restepo-Coupe, P. Ratana, K. Didan, S.R. Saleska, K. Ichii, S. Panuthai \& M. Gamo 2008. Multiple site tower flux and remote sensing comparisons of tropical forest dynamics in Monsoon Asia. Agricultural and forest meteorology 148(5):748-760.

Jennings, S.B., N.D. Brown \& D. Sheil 1999. Assessing forest canopies and understorey illumination: canopy closure, canopy cover and other measures. Forestry 72(1):59-74.

Kuznetsov, A.N. \& S.P. Kuznetsova 2013. Tropical monsoon forests of Vietnam (results of 20 years of phytoecological research). Biology Bulletin 40(2):187-196.

Kuznetsov, A.N. 2005. Tropical dipterocarp forest. GEOS, Moscow 140 pp. (in Russian). [Кузнецов А.Н. 2003. Тропический Аиптерокарповый мес. Москва: ГЕОС. 140 с.].

Lamb, D., P.D. Erskine \& J.A. Parrotta 2005. Restoration of degraded tropical forest landscapes. Science 310(5754): 1628-1632.

Lei, T.T., M. Lechowicz 1998. Diverse responses of maple saplings to forest light regimes. Annals of Botany 82(1):9-19.

Lichtenthaler, H.K. \& F. Babani 2004. Light adaptation and senescence of the photosynthetic apparatus. Changes in pigment composition, chlorophyll fluorescence parameters and photosynthetic activity. In: Chlorophyll a Fluorescence (G.C. Papageorgiou, Govindjee, eds), pp. 713-736, Springer, Dordrecht.

Lichtenthaler, H.K. 1987. Chlorophyll and carotenoids: pigments of photosynthetic biomembranes. Methods in Enaymology 148:350-382.

Lüttge, U. 2008. Physiological ecology of tropical plants, 2nd edition. Springer-Verlag, Berlin, 458 pp.

Markesteijn L., P. Lourens \& B. Frans 2007. Light-dependent leaf trait variation in 43 tropical dry forest tree species. American Journal of Botany 94(4):515-525.

McKnight, T.L. \& D. Hess 2000. Physical geography: a landscape appreciation, 6-th edition. Prentice Hall, New Jersey.

Niinemets, Ü. \& F. Valladares 2004. Photosynthetic acclimation to simultaneous and interacting environmental stresses along natural light gradients: optimality and constraints. Plant Biology 6(3):254-268.

Paletto, A. \& V. Tosi 2009. Forest canopy cover and canopy closure: comparison of assessment techniques. European Journal of Forest Research 128(3):265-272.

Pérez-Harguindeguy, N., S. Díaz, E. Garnier, S. Lavorel, H. Poorter, P. Jaureguiberry, M.S. Bret-Harte et al. 2013. New handbook for standardised measurement of plant functional traits worldwide. Australian Journal of Botany 61: 167-234.

Pigliucci, M. 2005. Evolution of phenotypic plasticity: where are we going now? Trends in Ecology \& Evolution 20(9): 481-486.

Popma, J., F. Bongers \& M.J.A. Werger 1992. Gap-dependence and leaf characteristics of trees in a tropical lowland rain forest in Mexico. Oikos 63(2):207-214.

Richards, P.W. 1952. The tropical rain forest. Cambridge University Press, Cambridge, $450 \mathrm{pp}$.

Rozendaal, D.M.A., V.H. Hurtado \& L. Poorter 2006. Plas- 
ticity in leaf traits of 38 tropical tree species in response to light: relationships with light demand and adult stature. Functional Ecology 20:207-216.

Sánchez-Gómez, D., M.A. Zavala \& F. Valladares 2006. Seedling survival responses to irradiance are differentially influenced by low-water availability in four tree species of the Iberian cool temperate-Mediterranean ecotone. Acta Oecologica 30(3):322-332.

Sultan, S.E. \& F.A. Bazzaz 1993. Phenotypic plasticity in Polygonum persicaria. I. Diversity and uniformity in genotypic norms of reaction to light. Evolution 47(4):1009-1031.

Sultan, S.E. 2000. Phenotypic plasticity for plant development, function and life history. Trends in Plant Science 5(12):537-542.

Sun, X., Z. Lu, P. Li, Q. Jiang \& Z. Lang 2006. Ecological adaptation of Eupatorium adenophorum populations to light intensity. Journal of Forestry Research 17(2):116-120.

Szarzynsk, J. \& D. Anhuf 2001. Micrometeorological conditions and canopy energy exchange of a neotropical rain forest (Surumoni-Crane Project, Venezuela). Plant Ecology 153(1-2):231-239.

Valladares, F. \& Ü. Niinemets 2008. Shade tolerance, a key plant feature of complex nature and consequences. Annual Review of Ecology, Evolution, and Systematics 39:237-257.

Valladares, F. 2003. Light heterogeneity and plants: from ecophysiology to species coexistence and biodiversity. Progress in Botany 64:439-471.
Valladares, F., D. Sanchez-Gomez \& M.A. Zavala 2006. Quantitative estimation of phenotypic plasticity: bridging the gap between the evolutionary concept and its ecological applications. Journal of Ecology 94(6):1103-1116.

Valladares, F., E. Martinez-Ferri, L. Balaguer, E. Perez-Corona \& E. Manrique 2000. Low leaf-level response to light and nutrients in Mediterranean evergreen oaks: a conservative resource-use strategy? New Phytologist 148(1): 79-91.

Vandekerckhove, K., R. de Wulf \& N.N. Chinh 1993. Dendrological composition and forest structure of Nam Bai Cat Tien National Park, Vietnam. WWF International, Aria and Pacific Programme, VN 0007, Project Report, Hanoi.

Whitmore, T.C. 1996. A review of some aspects of tropical rain forest seedling ecology with suggestions for further enquiry. In: The ecology of tropical forest tree seedlings. Programme on Man and the Biosphere, UNESCO series, vol. 17, pp. 3-39. Parthenon, Paris, France.

Wintermans, J.F.G.M. \& A. De Mots 1965. Spectrophotometric characteristics of chlorophylls $a$ and $b$ and their phenophytins in ethanol. Biochimica et Biophysica Acta 109(2):48-453.

Zhang, Y.P., Y.X. Ma, Y.H. Liu \& K.Y. Zhang 2000. Horizontal thermal characteristics at forest edges in a calm tropical area of China. Chinese Journal of Applied Ecology 11(2):205-209. 